\title{
DINAMIKA POPULASI ELANG JAWA (Nisaetus bartelsi) DI KAWASAN CAGAR ALAM GUNUNG PICIS DAN CAGAR ALAM GUNUNG SIGOGOR
}

\section{POPULATION DYNAMICS OF JAVAN HAWK-EAGLE (Nisaetus bartelsi) IN GUNUNG PICIS AND GUNUNG SIGOGOR NATURE RESERVE AREAS}

\author{
Gunawan 1, Tri Wahyu Widodo², Fajar DNA ${ }^{2}$, Imran Jamil ${ }^{3}$, Danafia Permana ${ }^{3}$ \\ 1. Yayasan Konservasi Elang Indonesia email: gunawan215@yahoo.com \\ 2. BBKSDA Jawa Timur \\ 3. PT. Pertamina (Persero) TBBM Madiun.
}

\begin{abstract}
ABSTRAK
Elang jawa termasuk salah satu satwa prioritas yang populasi alaminya perlu ditingkatkan sebanyak 10\%, sehingga BBKSDA Jawa Timur menentukan site monitoring yang diamati secara rutin untuk mengetahui dinamika populasinya. Pengamatan yang dilakukan di Cagar Alam (CA) Gunung Picis dan Cagar Alam (CA) Gunung Sigogor selama 7 hari setiap tahun pada bulan Juli-Agustus selama kurun waktu 2013 - 2018 menunjukkan bahwa populasi Elang jawa di kawasan tersebut mengalami peningkatan yang ditandai dengan adanya individuindividu muda dan perjumpaan di lokasi baru.
\end{abstract}

Kata kunci: elang jawa, raptor, populasi, Jawa Timur

\section{ABSTRACT}

Javan Hawk-Eagle is one of priority species which is natural population need to increase 10 percent, so that BBKSDA East Java chooses the monitoring site to monitor this species dynamic population. The observations which conduct in Gunung Picis and Gunung Sigogor Nature Reserve Areas for seven days in every years on July-August since 2013 until 2018 shows that Javan Hawk-Eagle population in those areas has been increase. The population increase show by juvenile individual and finding the species in new locations.

Keywords: javan hawk-eagle, raptor, population, East Java

PENDAHULUAN

Elang jawa (Nisaetus bartelsi) adalah salah satu jenis raptor endemik di Pulau Jawa yang dalam daftar merah IUCN termasuk dalam kategori terancam punah (endangered) (Gjershaug et al. 2004; Nijman et al. 2009; IUCN. 2018). Satwa ini telah ditetapkan sebagai lambang negara Indonesia (Widyastuti. 1993) dan menjadi salah satu dari 25 jenis satwa prioritas terancam punah yang populasi alaminya perlu ditingkatkan sebanyak $10 \%$ dalam kurun waktu 2015 sampai 2019 (Anonim. 2015).
Burung pemangsa (raptor), termasuk elang jawa, mempunyai kepekaan terhadap perubahan lingkungan (Poirazidis et al. 2007), sehingga sering dianggap sebagai species kunci (Sergio et al. 2008) dan juga indikator kondisi ekosistem yang sehat (Rodriguez-Estrella et al. 1998; Poirazidis et al. 2007). Kemudian, Hiraldo et al (1995) juga menyebutkan bahwa raptor juga mempunyai peranan penting dalam mengontrol penyakit di suatu kawasan.

Daerah jelajah elang jawa diperkirakan seluas $300 \mathrm{Ha}$ (Gjershaug et al. 2004). Berdasarkan hasil perhitungan yang dilakukan oleh Syartinilia et al (2009) 
populasi elang jawa diperkirakan adalah 325 pasang, dimana 117 diantaranya tersebar di Jawa Barat (Azmi et al. 2016). Van Balen (1999) menyebutkan bahwa elang jawa tersebar di kawasan hutan yang masih tersisa dari jawa bagian barat sampai jawa bagian timur. Populasi elang jawa semakin terancam akibat habitat yang semakin sempit, deforestasi hutan dan fragmentasi habitat dan perburuan serta perdagangan ilegal (Birdlife International. 2017). Gunawan et al (2017) menyebutkan bahwa sekitar 5\% dari 2.471 ekor raptor diurnal yang diperdagangkan adalah elang jawa.

CA Gunung Picis yang luasnya 29,7 Ha ditetapkan sebagai kawasan konservasi berdasarkan SK GB No. 36 Stbl. No. 43, 4 Pebruari 1924; sedangkan CA Gunung Sigogor dengan luas 190,5 Ha ditetapkan berdasarkan SK GB No. 23 Stbl. 471, 4 September 1936 (Setyawati. 2010). Keduanya adalah kawasan konservasi yang letaknya berdekatan dan merupakan habitat alami elang jawa (Aji et.al. 2016). Oleh karena itu, Balai Besar KSDA Jawa Timur secara rutin melakukan pemantauan populasi elang jawa di kedua kawasan tersebut. Paper ini berisi tentang dinamika populasi elang jawa di kedua kawasan tersebut berdasarkan hasil pemantauan rutin yang dilakukan oleh BBKSDA Jawa Timur bersama stakeholder nya.

\section{LOKASI PENELITIAN}

Penelitian ini dilakukan di CA Gunung Picis dan CA Gunung Sigogor yang secara administratif termasuk dalam wilayah Desa Pupus, Kecamatan Ngebel, Kabupaten Ponorogo, Provinsi Jawa Timur. Kedua kawasan yang berdekatan ini melingkupi area seluas 210,2 Ha yang secara geografi terletak pada $07^{\circ} 48^{\prime}$ $07^{\circ} 50^{\prime} \mathrm{LS}$ dan $111^{\circ} 36^{\prime}-111^{\circ} 38^{\prime} \mathrm{BT}$. Kawasan CA Gunung Picis dan CA Gunung Sigogor mempunyai topografi berbukit-bukit dengan kelerengan yang sedang hingga terjal dengan ketinggian 1.000-1.700 mdpl. Menurut Schmidt and Ferguson (1951), iklim di wilayah ini termasuk tipe $\mathrm{C}$ dimana rata-rata curah hujan tahunan adalah $2.582 \mathrm{~mm}$ dengan jumlah hujan sektar 142 hari. Kisaran suhu di area ini adalah $15-20{ }^{\circ} \mathrm{C}$ pada malam hari dan $30-35{ }^{\circ} \mathrm{C}$ pada siang hari (Setyawati. 2010).

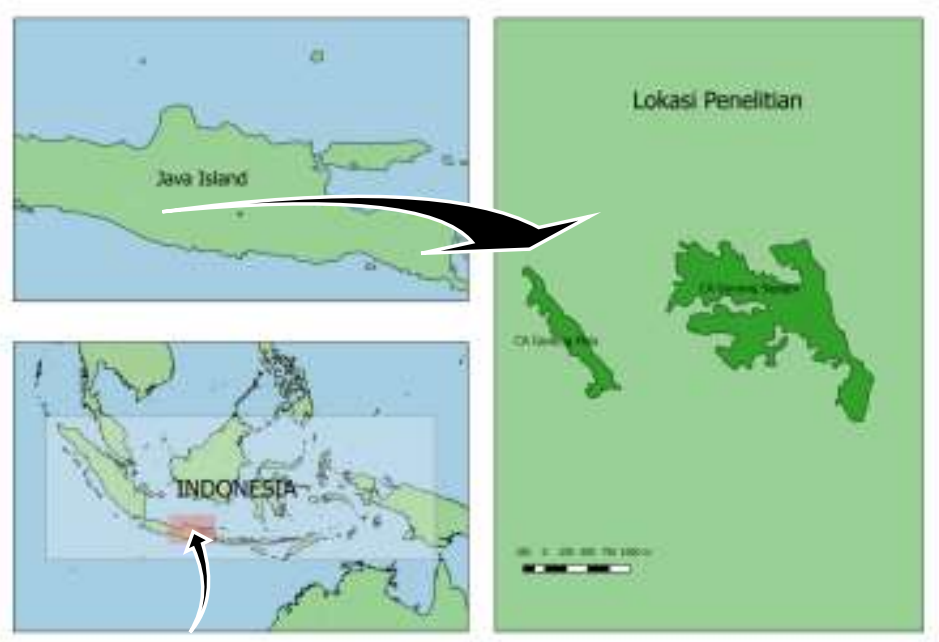

Gambar 1. Lokasi penelitian di CA Gunung Picis dan CA Gunung Sigogor, Ponorogo, Jawa Timur 
Menurut Setyawati (2010) tipe vegetasi di area ini adalah hutan hujan tropis pegunungan yang didominasi oleh pasang (Quercus sondaica), jamuju (Podocarpus imbricatus), rasamala (Altingia excelsa), salam (Eugenia polyantha). Sedangkan beberapa jenis fauna yang dapat dijumpai di area ini antara lain adalah rangkong badak (Buceros rhinoceros), macan tutul (Panthera pardus), monyet ekor panjang (Macaca fascicularis), dan lutung (Trachypithecus cristatus)

\section{METODE}

Mulai tahun 2012, kawasan CA Gunung Picis ditetapkan oleh BBKSDA Jawa Timur sebagai lokasi permanen pemantauan populasi elang jawa. Pada bulan Juli s.d Agustus, dilakukan monitoring secara periodik di kawasan tersebut. Pemantauan populasi elang jawa dengan menggunakan metode line transect dan point count (Bibby et al., 2000) dengan melibatkan 3 tim yang masing-masing terdiri dari 2 orang, yang dilakukan elama tujuh hari.

Guna kepentingan pengamatan masing-masing tim dibekali dengan alat pengamatan berupa binokuler Nikon monarch 5, kamera Canon 7D dengan lensa 300mm dan Canon 760D dengan lensa $135 \mathrm{~mm}$ dan kamera prosumer Canon SX60HS serta HT untuk alat komunikasi antar tim dan GPS untuk menentukan arah dan titik koordinat. Semua data tentang jenis, jumlah, perilaku, ciri khusus dan arah pergerakan dicatat dalam lembar pengamatan.

\section{HASIL DAN PEMBAHASAN}

Elang jawa diketahui hidup dari dataran rendah sampai ketinggian 3.000 mdpl (MacKinnon dan Phillipps, 1998). Rov et al.(1997) menyebutkan bahwa spesies ini menyukai daerah dengan ketinggian 200-2000 mdpl. Hal ini sesuai dengan data perjumpaan elang jawa di kawasan CA Gunung Sigogor dan CA Gunung Picis yang ketinggian lokasinya 1.000-1.700 mdpl.

Hasil monitoring periodik tahunan mulai tahun 2012 s.d tahun 2018, diketahui bahwa populasi alami elang jawa di CA Gunung Picis dan CA Gunung Sigogor terdistribusi di 6 (enam) lokasi (Gambar 2). Lokasilokasi perjumpaan elang jawa di kedua cagar alam tersebut ditemukan secara bertahap sebagaimana tercantum dalam Tabel 1 di bawah ini.

Tebel 1. Data perjumpaan elang jawa di kawasan CA Gunung Sigogor dan CA Gunung Picis

\begin{tabular}{|c|c|c|c|c|c|c|c|c|c|c|c|c|c|c|c|c|c|c|c|c|}
\hline $\begin{array}{c}\text { Distribusi } \\
\text { Populasi } \\
\text { Elang Jawa }\end{array}$ & 2012 & 2013 & 20 & & 201 & & & 016 & & \multicolumn{5}{|c|}{2017} & \multicolumn{6}{|c|}{2018} \\
\hline Lokasi & $\mathrm{A}$ & $\mathrm{A}$ & $\mathrm{A}$ & B & $\mathrm{A}$ & B & $\mathrm{A}$ & B & $\mathrm{C}$ & A & B & $\mathrm{C}$ & 1 & 2 & $\mathrm{~A}$ & B & $\mathrm{C}$ & 1 & 2 & 3 \\
\hline $\begin{array}{l}\text { Anakan/ } \\
\text { Remaja }\end{array}$ & - & 1 & 1 & - & - & 1 & - & 1 & 1 & 1 & 1 & - & 1 & - & - & 1 & - & - & - & 1 \\
\hline Dewasa & - & 2 & - & 2 & - & 2 & - & 1 & - & - & 1 & - & 2 & 2 & 1 & 1 & - & 1 & 1 & 1 \\
\hline
\end{tabular}


Dari tabel 1 diketahui bahwa elang jawa di kawasan tersebut baru dijumpai pada tahun 2013 di CA Gunung Picis, yang selanjutnya dilakukan pemantauan secara rutin hingga tahun 2018. Elang jawa yang dijumpai di lokasi ini berjumlah 3 individu yang terdiri dari 2 individu dewasa dan 1 individu remaja. Kemudian pada tahun 2014, tim menemukan 1 individu elang jawa remaja di lokasi yang sama. Di lokasi lain yang jaraknya tidak terlalu jauh $(<1 \mathrm{~km})$, tim menemukan sepasang elang jawa dewasa. Hasil pengamatan menunjukkan bahwa elang jawa di kedua lokasi tersebut mempunyai daerah jelajah yang berbeda.

Pada tahun 2015, tim monitoring tidak menemukan elang jawa di lokasi pertama (lokasi A), namun menjumpai 3 ekor elang jawa yang terdiri dari 2 ekor individu dewasa dan 1 individu remaja yang usianya diperkirakan lebih muda dari elang jawa remaja sebelumnya. Diperkirakan ketiga elang jawa tersebut adalah satu keluarga.

Tahun 2016 dilakukan pelepasan elang jawa remaja di lokasi yang tidak jauh dari lokasi perjumpaan elang jawa pertama dengan harapan dia bisa berpasangan dengan elang jawa muda yang pernah dijumpai di lokasi A. Namun elang jawa tersebut bergeser ke arah perkampungan dan diketahui ditangkap oleh masyarakat pada hari ke 35 setelah pelepasan. Di tahun 2016, tim hanya menjumpai 1 individu elang jawa dewasa dan 1 individu elang jawa remaja di lokasi B. Berdasarkan ciri fisiknya, diperkirakan elang jawa muda ini adalah anakan yang dijumpai di tahun 2015 . Hal ini sesuai dengan yang disampaikan oleh Gunawan et al (2016) yang menyatakan bahwa elang jawa berbiak setiap 2-3 tahun sekali.

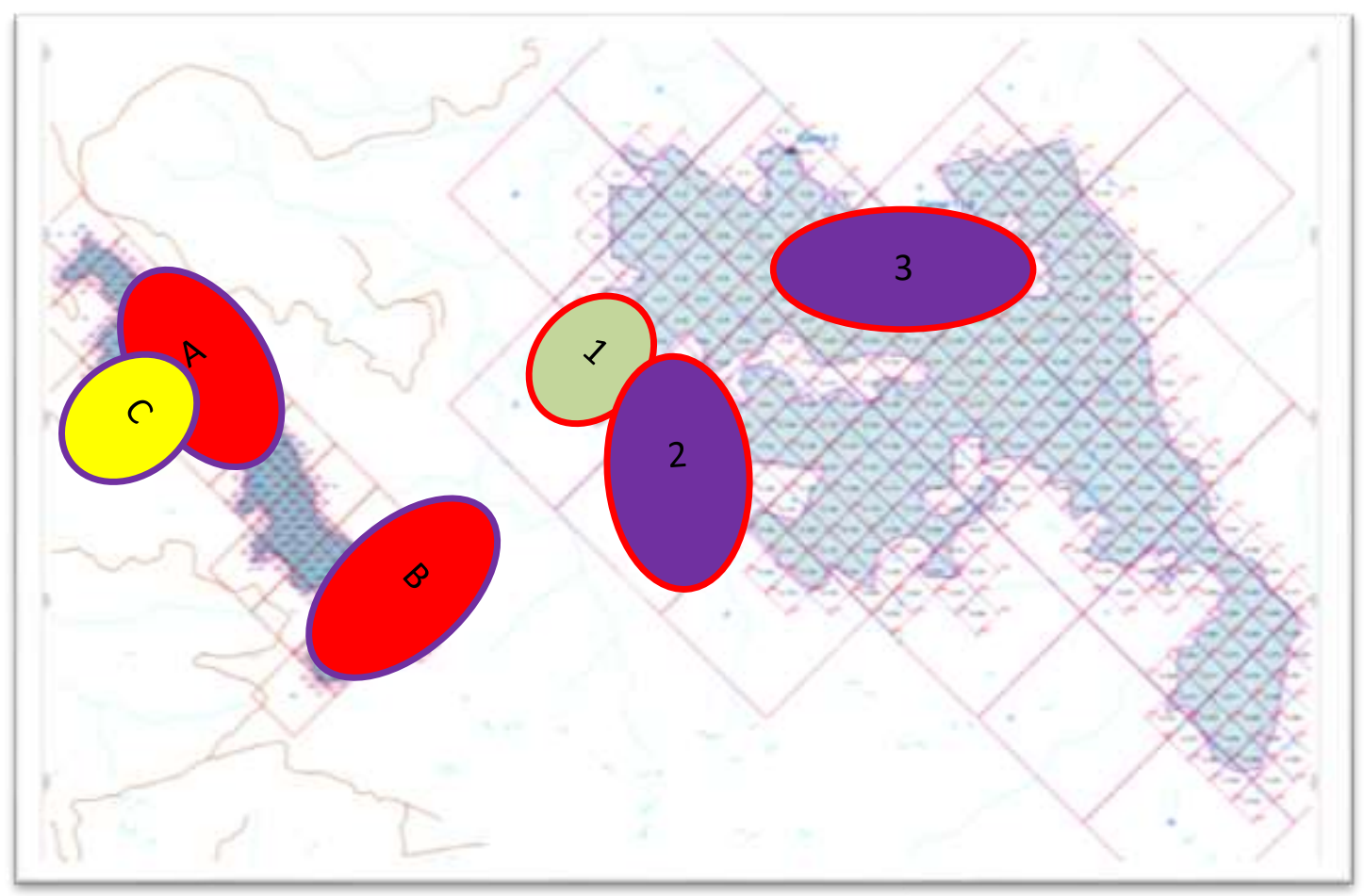

Gambar 2. Distribusi Populasi Elang Jawa di CA Gunung Picis dan CA Gunung Sigogor 
Pada tahun 2017, kembali dilakukan pelepasliaran satu ekor individu muda elang jawa di CA Gunung Sigogor (lokasi 1). Selama hampir 40 hari dipantau menggunaan satelit tracker, diketahui bahwa elang jawa ini bergerak menyusuri sungai sejauh hampir $7 \mathrm{~km}$ hingga akhirnya keluar dari kawasan CA Gunung Sigogor. Di tahun 2017 juga dilakukan pelepasliaran kembali elang jawa yang sebelumnya pernah dilepaskan tahun 2016. Hingga tahun 2018, elang hasil lepasan ini masih dijumpai menetap di sekitar lokasi pelepasan. Di tahun 2017, tim menemukan 1 individu elang jawa dewasa yang muncul saat dilakukan habituasi untuk elang jawa yang akan dilepasliarkan di CA Gunung Sigogor. Elang jawa ini menjadi elang jawa liar yang ditemukan pertama di CA Gunung Sigogor (lokasi 2).
Di tahun 2018, dilakukan survey seluruh kawasan CA Gunung Picis dan CA Gunung Sigogor yang melibatkan 72 orang. Hasil dari survey ini adalah: 1 elang jawa dewasa di lokasi A; 1 elang jawa muda dan 1 dewasa di lokasi B; 1 elang jawa dewasa di lokasi 1 (hasil lepasan); 1 elang jawa dewasa di lokasi 2; serta 1 elang jawa muda dan 1 dewasa di lokasi baru (lokasi 3). Diperkirakan elang jawa muda yang teramati adalah anakan baru yang menetas di tahun 2018.

Dengan asumsi bahwa elang jawa memilih pasangan yang usianya tidak terpaut jauh, setelah dilakukan penghitungan dengan mempertimbangkan adanya kemungkinan indukan dari individu muda dan pasangan dari individu dewasa, maka populasi elang jawa di kedua kawasan tersebut dapat diperkirakan sebagai berikut:

Tebel 2. Estimasi populasi elang jawa di kawasan CA Gunung Sigogor dan CA Gunung Picis

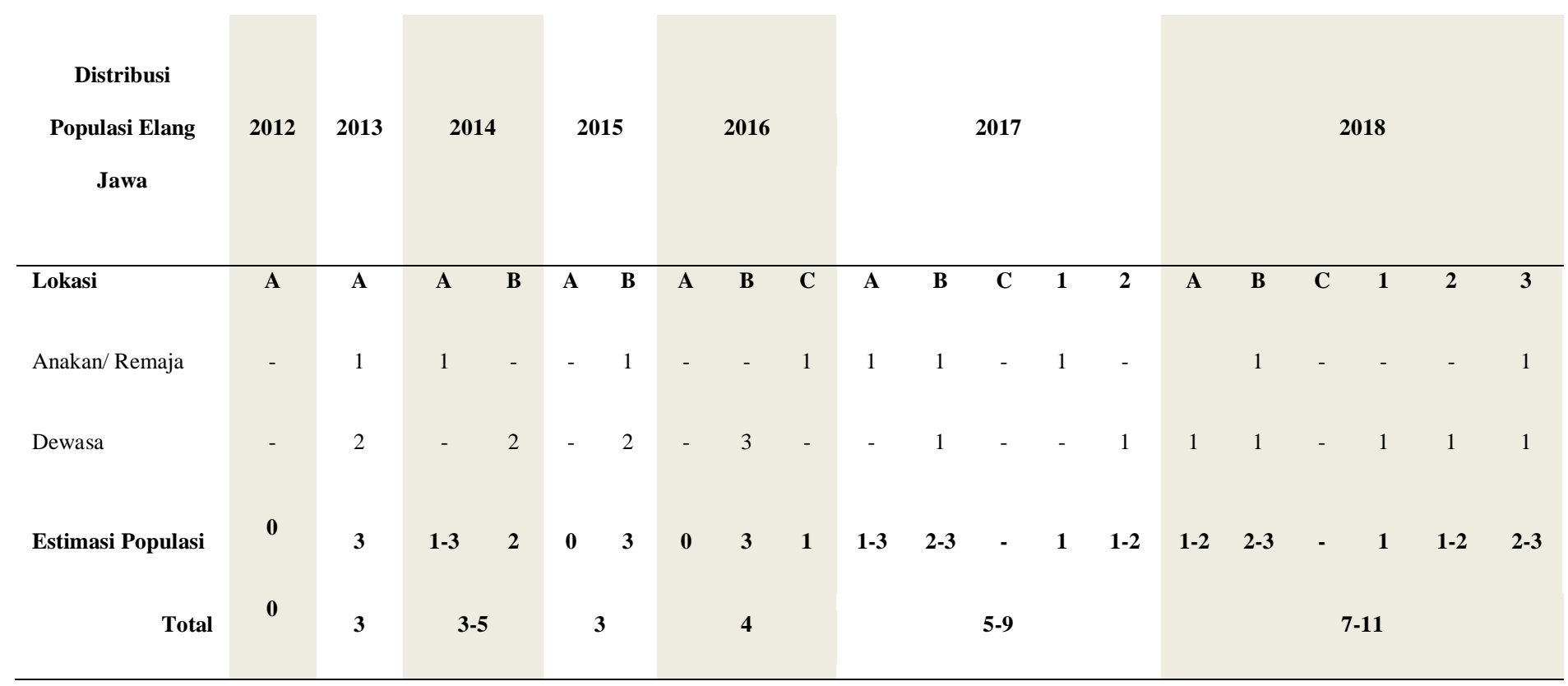


Sehingga dinamika populasi elang jawa di kedua kawasan konservasi tersebut dapat dilihat pada gambar di bawah ini:

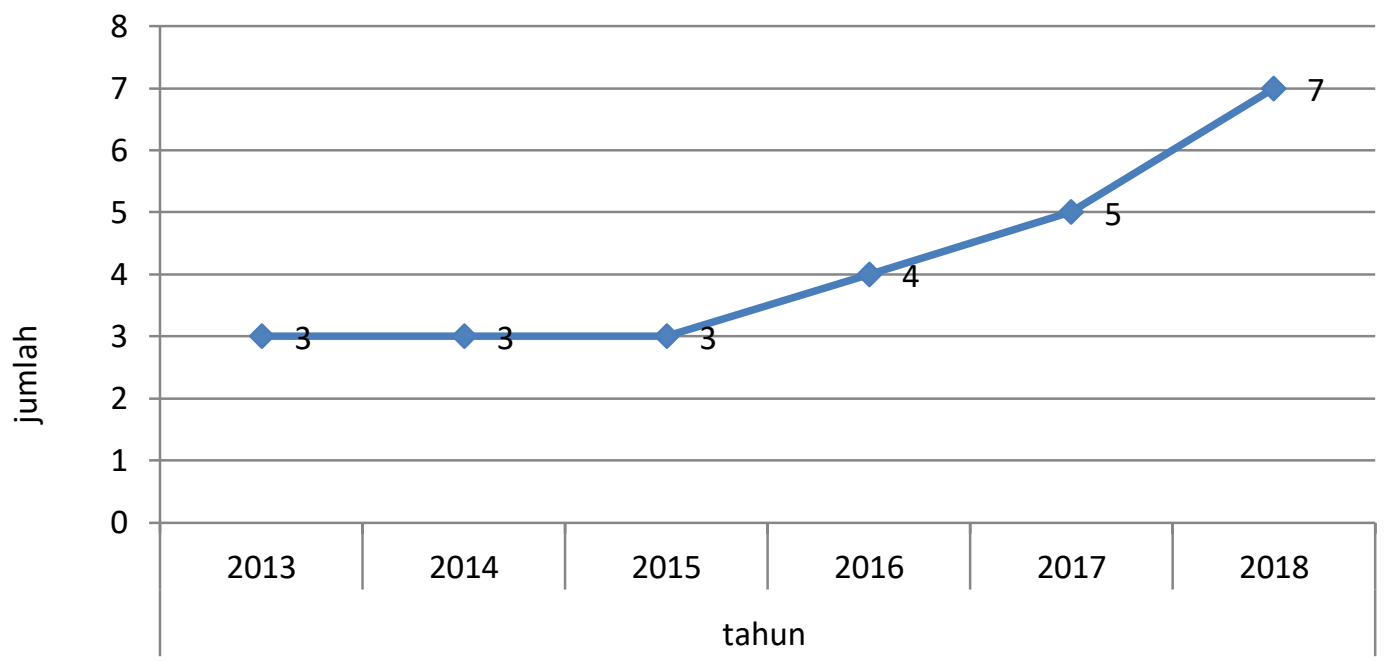

Gambar 3. Dinamika populasi elang jawa di kawasan CA. Gunung Picis dan CA Gunung Sigogor

Berdasarkan data di atas, populasi elang jawa di kawasan CA Gunung Picis dan CA Gunung Sigogor telah mengalami kenaikan sekitar 233\% dalam kurun waktu 2013-2018. Kenaikan jumlah ini selain disebabkan adanya program pelepasliaran juga disebabkan karena adanya perjumpaan elang jawa di lokasi yang baru.

Data di atas juga menunjukkan bahwa CA Gunung Picis dan CA Gunung Sigogor yang luas total dari kedua kawasan itu 210,2 Ha mempunyai populasi elang jawa yang cukup tinggi. Kemampuan kedua kawasan konservasi menampung populasi elang jawa yang cukup tinggi tidak lepas dari kondisi kawasan penyangganya, sebagaimana pernyataan Gjershaug et al.
(2004) dan Nijman et al. (2009) yang menyatakan bahwa elang jawa sangat bergantung pada hutan.

\section{KESIMPULAN}

Pengamatan yang dilakukan di Cagar Alam (CA) Gunung Picis dan Cagar Alam (CA) Gunung Sigogor selama 7 hari setiap tahun pada bulan Juli-Agustus selama kurun waktu 2013 - 2018 menunjukkan bahwa populasi Elang jawa di kawasan tersebut mengalami peningkatan yang ditandai dengan adanya individu-individu muda dan perjumpaan di lokasi baru. 


\section{UCAPAN TERIMA KASIH}

Terima kasih dan penghargaan setinggi-tingginya kami ucapkan kepada BBKSDA Jawa Timur dan seluruh jajarannya, PT. Pertamina TBBM Madiun, serta semua panitia dan peserta Summer Camp 2018, masyarakat Desa Seketip, Ponorogo dan semua pihak yang telah mendukung penelitian ini.

\section{DAFTAR PUSTAKA}

Aji, F.D.N., Gunawan, Asman A.A, Resia H., Adi A.P. 2016. Laporan pelepasliaran elang jawa (Nisaetus bartelsi) hasil sitaan ke habitat alaminya di Cagar Alam Gunung Picis, PoborogoJawa Timur.

Aji, F.D.N., Gunawan, Rully M., Tauhid N., Sigit T., Saiful H. 2017. Laporan monitoring elang jawa (Nisaetus bartelsi) hasil lepasan di kawasan Cagar Alam Gunung Sigogor, Ponorogo, Jawa Timur.

Anonim. 2015. Peraturan Menteri Kehutanan Republik Indonesia Nomor :P.58/Menhut-Ii/2013 Tentang Strategi Dan Rencana Aksi Konservasi Elang Jawa (Spizaetus Bartelsi) Tahun 20132022.

Azmi, N, Syartinilia, Y.A. Mulyani. 2016. Model Distribusi Spasial Habitat Elang Jawa (Nisaetus bartelsi) Yang Tersisa Di Jawa Barat. Media Konservasi Vol. 21 No. 1: 9-18

Bibby, CJ, Burgess, ND., Hill, DA \& Mustoe, SH. 2000. Bird Census Techniques (2nd Ed). Academic Press, Tokyo.

Bird Life International 2017. Nisaetus bartelsi (amended version of 2016 assessment). The IUCN Red List of Threatened Species 2017: e.T22696165A110050373. https://dx
.doi.org/10.2305/IUCN.UK.2017-

1.RLTS.T22696165A110050373.en.

Downloaded on 10 March 2020.

Gjershaug J.O., Røv N., Nygard T., Prawiradilaga D.M., Afianto M.Y., Hapsoro M.Y. \& Supriatna A. 2004. Home-range size of the Javan HawkEagle (Spizaetus bartelsi) estimated from direct observations and radiotelemetry. Journal of Raptor Research, 38: 343-349.

Gunawan, Nani, R. Fauziah, Zulham, Djamaludin, H. Pramono \& A. Yuniar. 2016. New homes on misty mountains: Javan Hawk-eagle Nisaetus bartelsi and Changeable Hawk-eagle Nisaetus cirrhatus nesting in Gunung Halimun Salak National Park, West Java, Indonesia. Podoces 11:1-6.

Gunawan, Ahmad Paridi \& Richard Noske. 2017. The use of social media in the illegal trade in Indonesian raptors. Kukila. 20: 1-10

Hiraldo F., Donázar J.A., Ceballos O., Travaini A., Bustamante J. \& Funes M. 1995. Breeding biology of a grey eaglebuzzard population in Patagonia. The Wilson Bulletin, 675-685.

IUCN. 2108. The IUCN Red List of Threatened Species. Version 2018.3. Http://www.iucnredlist.org.

MacKinnon, J., Phillipps, K. \& Balen, S. van. 1998. Burung-burung di Sumatera, Jawa, Bali dan Kalimantan (termasuk Sabah, Sarawak dan Brunei Darrussalam). Puslitbang Biologi-LIPI Jakarta.

Nijman V., Shepherd C.R. \& van Balen S. (2009). Declaration of the Javan hawk eagle Spizaetus bartelsi as Indonesia's National Rare Animal impedes conservation of the species. Oryx, 43: 122-128. 
Poirazidis K., Goutner V., Tsachalidis E. \& Kati V. (2007). Comparison of nest-site selection patterns of different sympatric raptor species as a tool for their conservation. Animal Biodiversity and Conservation, 30: 131-145.

Rodríguez-Estrella, R., Donázar, J. A. \& Hiraldo, F. (1998) Raptors as indicators of environmental change in the scrub habitat of Baja California Sur, Mexico. Conserv. Biol. 12: 921-925. Schmidt, F.H. and J. H. A Ferguson. 1951. Rainfall Types Based on Wet and Dry Period Ratios for Indo-nesian with Western New Guinea. Kementrian Perhubungan Jawatan Meteorologi dan Geofisika. Jakarta.

Røv, N., Gjershaug, J.O., Prawiradilaga, D .M., Hapsoro, \& Supriatna, A.A. 1997. Conservation Biology of the Javan Hawk-eagle. Progress report prepared for the Indonesian Institute of Sciences (LIPI) and the Ministry of State for Environment (LH), Bogor, Indonesia.

Schmidt, F.H. and J. H. A Ferguson. 1951. Rainfall Types Based on Wet and Dry Period Ratios for Indo-nesian with Western New Guinea. Kementrian Perhubungan Jawatan Meteorologi dan Geofisika. Jakarta.

Sergio, F., Caro, T., Brown, D., Clucas, B., Hunter, J., Ketchum, J., McHugh, K. \& Hiraldo, F. (2008) Top predators as conservation tools: eco-logical rationale, assumptions, and efficacy. Annu. Rev. Ecol. Evol. Syst. 39: 1-19.

Setyawati, T. 2010. Pemanfaatan Pohon Berkhasiat Obat di Cagar Alam Gunung Picis dan Gunung Sigogor, Kabupaten Ponorogo, Jawa Timur. Penelitian Hutan dan Konservasi Alam. Vol. VII No.2: 177-192 Thiolay, J.M. \& Meyburg, B.U. 1988. Forest fragmentation and the conservation of raptors: A survey on the island of Java. Biologicaal Conservation, 44(4): 229-250

Syartinilia, Tsuyuki S, Lee JS. 2009. A habitat model for the Javan Hawk-Eagle (Spizaetus Bartelsi) using multi-scale approach in Java Island, Indonesia. Wildlife: Destruction, Conservation and Biodiversity. 9(2009): 301-312.

Van Balen, B. 1999. Birds on fragmented islands : persistence in the forests of Java and Bali. Doctoral thesis. Wageningen University and Research Centre, The Netherlands.

Widyastuti, Y.E. 1993. Flora-fauna maskot nasional dan propinsi. Penebar Swadaya, Jakarta, Indonesia. 